\title{
Spatial distribution, habitat preference and colonization status of two alien terrestrial invertebrate species in Antarctica
}

\author{
KEVIN A. HUGHES* and M. ROGER WORLAND* \\ British Antarctic Survey, NERC, High Cross, Madingley Road, Cambridge CB3 OET, UK \\ kehu@bas.ac.uk
}

\begin{abstract}
The introduction of invasive species is one of the greatest threats to Earth's biodiversity, as they can reduce native biodiversity and alter ecosystem structure and function. Currently, the only two known non-native terrestrial invertebrates in Antarctica are the chironomid midge Eretmoptera murphyi and the enchytraeid worm Christensenidrilus blocki. These invertebrates were probably introduced to ground near Signy Research Station, South Orkney Islands, during transplantation experiments in the late 1960s. Between 2007 and 2009, this study surveyed the area around the introduction site for midge larvae and worms to assess any change over the last four decades in their spatial distribution, habitat preference and colonization status. Eretmoptera murphyi was found in concentrations up to $4.1 \times 10^{5}$ larvae $\mathrm{m}^{-2}$ (mean $2.1 \times 10^{4}$ larvae $\left.\mathrm{m}^{-2}\right)$ at distances of up to $220 \mathrm{~m}$ from the probable introduction site $\left(c .35000 \mathrm{~m}^{2}\right)$, while C. blocki was only found close to the introduction site in low numbers. Significantly more E. murphyi larvae were found in peat and dead organic material $\left(3.34 \times 10^{4} \mathrm{~m}^{-2}\right)$ than in stony soil and gravel $\left(1.52 \times 10^{4} \mathrm{~m}^{-2}\right)$ or living moss and other plant material $\left(1.16 \times 10^{4} \mathrm{~m}^{-2}\right)$. Eretmoptera murphyi can no longer be considered a persistent alien as it clearly expanding its distribution, while $C$. blocki remains a persistent alien species.
\end{abstract}

Received 28 July 2009, accepted 5 October 2009

Key words: chironomid, enchytraeid, establishment, invasive, non-indigenous, Signy Island

\section{Introduction}

Invasions by non-native species are one of the greatest threats to global biodiversity (McKinney \& Lockwood 1999). Invasive species can alter existing species assemblages and ecosystem function (Mack et al. 2000) to the degree that entire landscapes can be transformed (Scott \& Kirkpatrick 2008). The majority of terrestrial ecosystems on Earth have already been impacted by invasive species, including many of the sub-Antarctic islands but, although at risk, to date Antarctica has remained so far largely protected from impact by invasive species (Frenot et al. 2005, 2008, Chown et al. 2008, Convey 2008).

The Antarctic terrestrial biota includes both relict species that have been present in Antarctic refugia on multimillion year timescales throughout glacial cycles, some since the breakup of Gondwana (Convey et al. 2008), and species that have colonized since then (Barnes et al. 2006). Potential colonizing species have to overcome two major barriers, termed the transport barrier and the establishment barrier. The colonization of Antarctica by non-native species has been considered to be an unlikely event as Antarctica's extreme isolation and the circumpolar oceanic and atmospheric currents create a high barrier to natural transport and the extreme climatic conditions (low temperatures and water availability) and paucity of suitable habitat make establishment difficult. However, increased human activity in Antarctic, in particular tourism

*Both authors contributed equally to this work. and national governmental operator activities, has increased the opportunity for non-native species to be transported to Antarctica (Frenot et al. 2005, Whinam et al. 2005, COMNAP 2009, IAATO 2009, Hughes et al. 2009, Lee \& Chown 2009). In addition, regional climate change may increase temperatures and water availability in some areas, making establishment more likely.

Since the arrival of humans on the sub-Antarctic islands for commercial activities in the late eighteenth and early nineteenth centuries, the number of non-native species has steadily increased, with c. 200 vertebrates, plants and invertebrates currently being known to be established (Frenot et al. 2005). This has resulted in major changes to the terrestrial environment (see reviews by Frenot et al. 2005, 2008). In contrast, only five non-native species are confirmed to have become established in the Antarctic terrestrial environment, including three grass and two invertebrate species. The two invertebrates, Eretmoptera murphyi Schaeffer and Christensenidrilus blocki Dozsa-Farkas \& Convey, are found close to the United Kingdom's Signy Research Station (South Orkney Islands; 6043'S 45⒊' W), and may result from the importation of non-sterile soil and plants during transplant experiments from South Georgia (Edwards 1980, Block et al. 1984, Convey \& Block 1996).

Introduction of non-Antarctic soil to Signy in the 1960s

Non-Antarctic soil was first intentionally introduced to Signy Island in 1963/64 when pieces of Polytrichum 


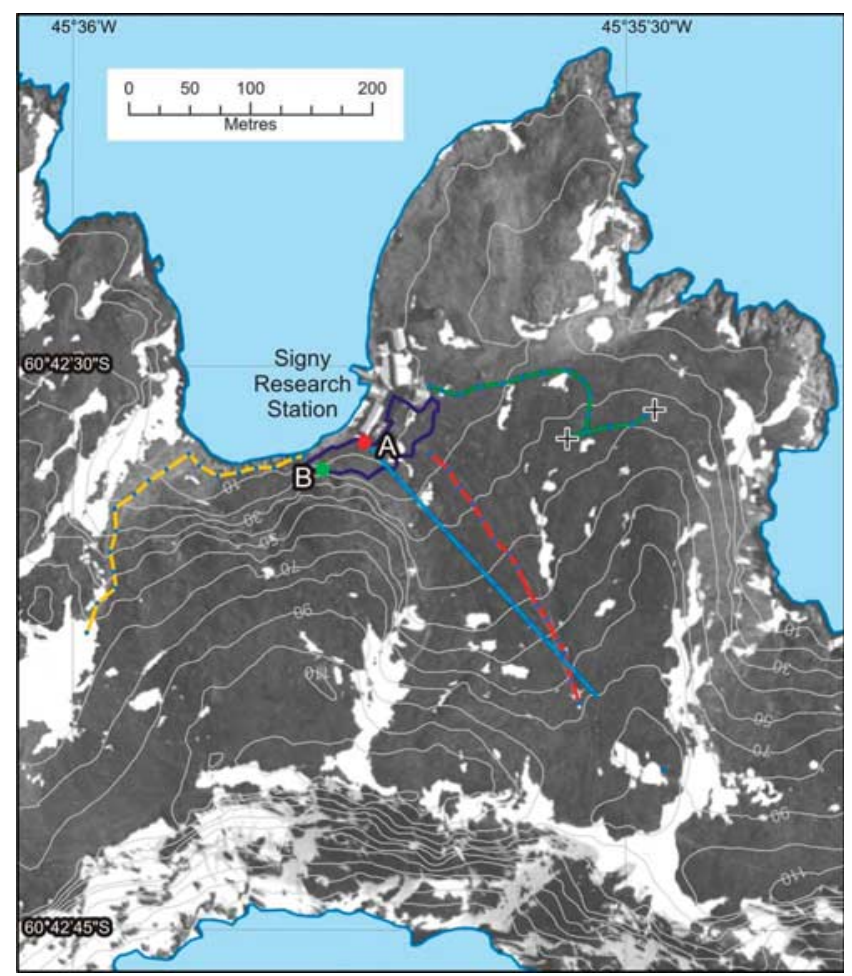

Fig. 1. Map of the Signy Research Station area showing the main introduction site $(A)$, the vermiculite site $(B)$. Blue line $=$ back slope transect, yellow line $=$ Stone Chute path, red line $=$ Back Slope path, and green line $=$ Study Site path ( + indicates position of cloches).

strictum Menzies ex Bridel turf were transplanted from South Georgia (R.I.L. Smith, personal communication 2008). In 1965, transplantation experiments continued using plants from the Falkland Islands and the Cairngorm Mountains, Scotland, all of which died in the first year and were incinerated in 1967 (Smith 1996).

In 1967 further transplantation experiments were performed, which probably resulted in the introduction of the two non-native invertebrate species to Signy from South Georgia (Edwards 1980). The main introduction site was on steeply sloping ground $\sim 25 \mathrm{~m}$ inland from Factory Cove, close to Signy Research Station, in an eroded Polytrichum alpestre Hoppe moss bank which was dug over and substituted with additional soil from sites in the local area (labelled A on Fig. 1). This site faced NNE on a $20^{\circ}$ slope around $13 \mathrm{~m}$ above sea level (Edwards \& Greene 1973). A second experimental site was set up $\sim 40 \mathrm{~m} \mathrm{WSW}$ of the main site, where plants were grown in vermiculite in pots supported by stones on an unstable NNW-facing slope $10 \mathrm{~m}$ above sea level and c. $25 \mathrm{~m}$ from the coast (Edwards 1968, Edwards \& Greene 1973) (labelled B on Fig. 1).

Vascular plants were collected from King Edward Point, Bore Valley and Husvik on South Georgia in early December 1967 and planted on Signy Island on 23 and 24 December 1967. A second collection of plants was made
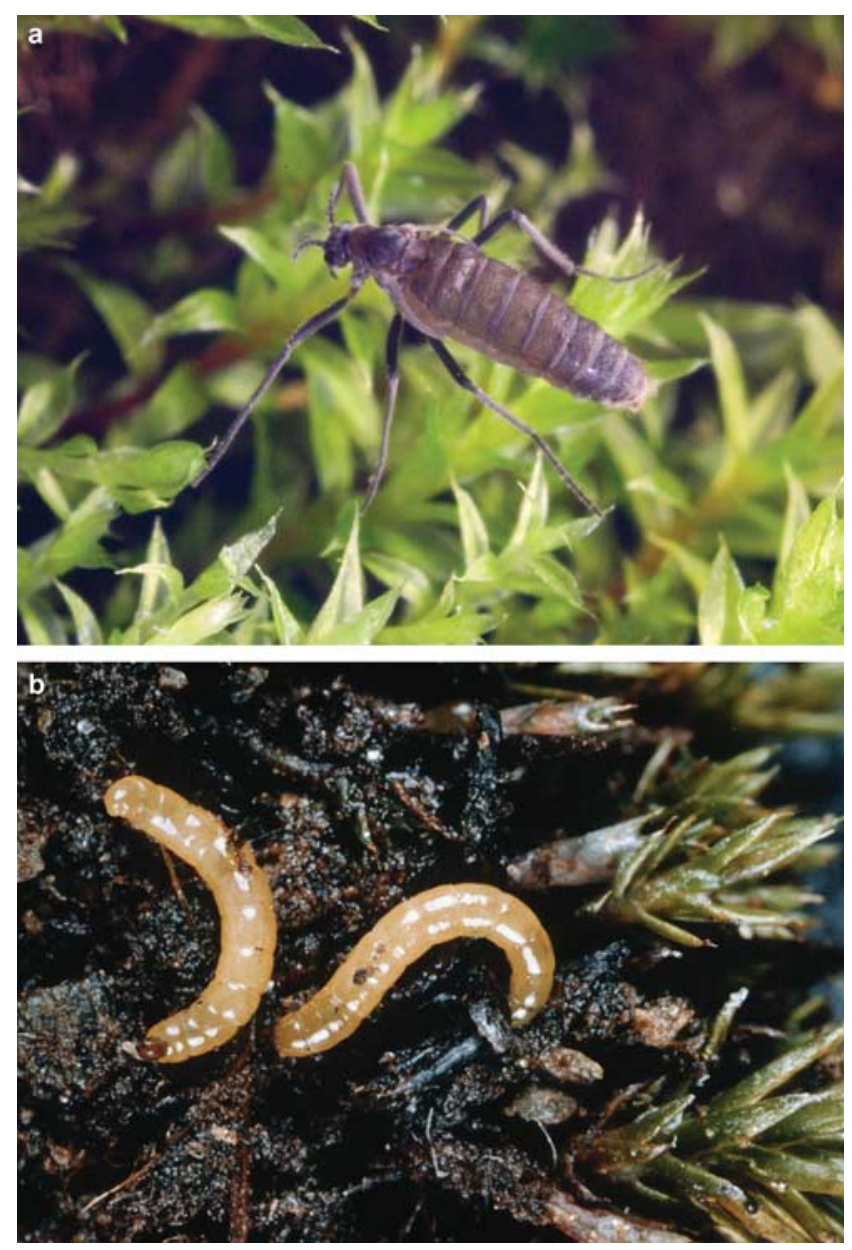

Fig. 2. a. Photograph of the Eretmoptera murphyi adult. The adult midge is approximately $4.5 \mathrm{~mm}$ long. b. Photograph of Eretmoptera murphyi larvae. Each larva is approximately $3.5 \mathrm{~mm}$ long.

from East Cumberland Bay on 18 November 1968 and planted on Signy between 2-4 December 1968 (Edwards 1980). All South Georgian plant material was removed and destroyed in February 1973 at the end of the research project. Translocated plant species included Acaena magellanica (Lam.) Vahl., A. tenera Alboff., Achillea millefolium L., Blechnum penna-marma (Poir.) Kuhn., Callitriche antarctica Engelm., Colobanthus subulatus (D’Urv.) Hook. f., C. quitensis (Kunth) Bartl., Cystopteris fragilis (L.) Bernh., Deschampsia antarctica Desv., Festuca contracta T. Kirk, Hymenophyllum falklandicum Baker, Juncus scheuchzerioides Gaud., Montia fontana L., Paradiochloa (Poa) flabellata (Lam.) Hook. f., Phleum alpinum L., Poa апnиa L., Poa pratensis L., Polystichum mohrioides (Bory) Pr., Ranunculus biternatus Smith, $R$. literatus Smith, $R$. repens L., Rostkovia magellanica (Lam.) Hook. f., Trifolium repens L. and Uncinia meridensis Steyermark. Of these, P. annua, P. pratensis, $A$. millefolium, $T$. repens and $R$. repens were originally nonnative to South Georgia (Edwards 1980, Smith 1996). 
Burn (1982) first reported the discovery of a non-native enchytraeid worm and a flightless chironomid midge on Signy Island at the main experimental site (labelled ' $\mathrm{A}$ ' in Fig. 1) on 27 September 1980, almost 13 years after the original probable introduction (Block et al. 1984). The two nonnative species were later identified as the chironomid midge Eretmoptera murphyi (Fig. 2a \& b) and the enchytraeid worm Christensenidrilus blocki. (Cranston 1985, Dózsa-Farkas \& Convey 1997, 1998). Although the transplant experiments were the most probable source of the introductions, arrival via this route does not explain either the apparent 13 year delay in the discovery of the two non-native species in an area frequently visited by terrestrial biologists, nor why E. murphyi has yet to be found at the South Georgia plant collection sites. A plausible alternative explanation is that the species introduction was associated with people and cargo that was routinely moved between South Georgia and Signy Research Station over many years.

\section{Eretmoptera murphyi}

Eretmoptera murphyi is a terrestrial brachypterous chironomid midge originally endemic to South Georgia, from where it has been reported on just a few occasions (Brundin 1970, Ring et al. 1990, Allegrucci et al. 2006). Prior to the introduction of E. murphyi, no native dipterans had been recorded from the South Orkney Islands (Convey 1992).

Larvae range from c. $1.5-5.0 \mathrm{~mm}$ in body length, pupae, c. $2.5-5.0 \mathrm{~mm}$, and adults, c. $3.4-4.9 \mathrm{~mm}$ (Block et al. 1984 , Cranston 1985), while live weights of freshly collected specimens range from $0.46-4.76 \mathrm{mg}$ (larvae), $1.01-2.04$ (pupae) and 0.18-1.16 mg (adults) (Block et al. 1984). On Signy, adult midges are generally observed emerging from pupal cases, with some degree of synchronicity, during calm sunny weather in early January. The adults crawl over the surface and are able to hold firm against wind currents (Block et al. 1984). Individuals produce single spherical egg batches containing c. 85 eggs, which are positioned beneath the substratum surface (Convey 1992, Convey \& Block 1996). Larvae hatch in late February about 30-45 days after oviposition and spend the winter in the surface layers of the soil and vegetation. Convey (1992) suggested that E. murphyi at Signy Island may follow a two year life-cycle, including two winters. This is supported by the large variation in larval fresh weight $(0.46-4.76 \mathrm{mg})$ which may represent cohorts hatched during different years (Convey \& Block 1996). At Signy Island, the larvae may require a second year (or possibly more) to complete development, due to the shorter period during which habitat temperatures are suitable for activities including feeding (low positive temperatures). Typically, annual mean air temperatures are $c .-3^{\circ} \mathrm{C}$ (range +11 to $-30^{\circ} \mathrm{C}$; data for 2006 ), while summer mean air temperatures are $c$. +1.0 (range +11 to $-3^{\circ} \mathrm{C}$; data for December 2006 to February 2007). Snow cover on Signy
Island is unpredictable and in years with little snow cover the winter soil temperatures can fall to below $-10^{\circ} \mathrm{C}$ (Bokhorst et al. 2008). It is possible that E. murphyi on South Georgia are able to complete their life cycle in one year as a result of the less harsh climatic conditions compared to Signy Island.

\section{Christensenidrilus blocki}

The distribution, taxonomy, physiology and ecology of terrestrial annelid worms in Antarctica are poorly known (Block \& Christensen 1985). The Acanthodrilidae and Lumbricidae extend only as far as the sub-Antarctic islands, but the Enchytraeidae penetrate further south to include the maritime Antarctic in their distribution (Dózsa-Farkas \& Convey 1997, Frenot et al. 2005). Block \& Christensen (1985) list 23 Enchytraeidae from the Antarctic and sub-Antarctic, including records of five new species from South Georgia that are common in northern Europe and which may have been introduced through human activities. Marine Antarctic enchytraeid species obtained from littoral collections at Signy Island include Lumbricillus lineatus Müller and L. maximus Michaelsen though no native terrestrial enchytraeids have been identified (Stephenson 1932). The enchytraeid introduced to Signy Island was identified as a new genus and named Christensenidrilus blocki (Block \& Christensen 1985, Dózsa-Farkas \& Convey 1997, 1998). Specimens, previously identified as Marionina georgiana Michaelsen and reclassified as Christensenidrilus blocki based on identical morphologies, were previously found on South Georgia within moss at East Cumberland Bay (Stephenson 1932). This is one of the locations from where plants were collected in 1968 for transplantation experiments on Signy (Edwards 1980).

Research and monitoring is essential if introduced species are to be managed and, if possible, eradicated. Since the introduction of E. murphyi and C. blocki to Signy Island, no systematic survey of their distribution has been undertaken. This study aims to assess the current spatial distribution, substratum preference and colonization status of terrestrial Antarctica's only two known non-native invertebrate species.

\section{Methods}

Quantification of non-native species in different substrata around the main introduction site

In January 2007, soil samples (four replicates) were taken at random (but within $50 \mathrm{~cm}$ ) of points on a $5 \times 5 \mathrm{~m}$ grid, centred on the main introduction site (labelled ' $\mathrm{A}$ ' on Fig. 1), using a $25 \mathrm{~mm}$ diameter corer to a depth of about $2.5 \mathrm{~cm}$. In addition, nine cores were collected from the main introduction site, which was $c .3 \mathrm{~m}$ by $3 \mathrm{~m}$ (using a $1.5 \mathrm{~m}$ matrix). Samples were immediately placed in sterile plastic bags and stored at $+4^{\circ} \mathrm{C}$ until returned for analysis in the UK. 


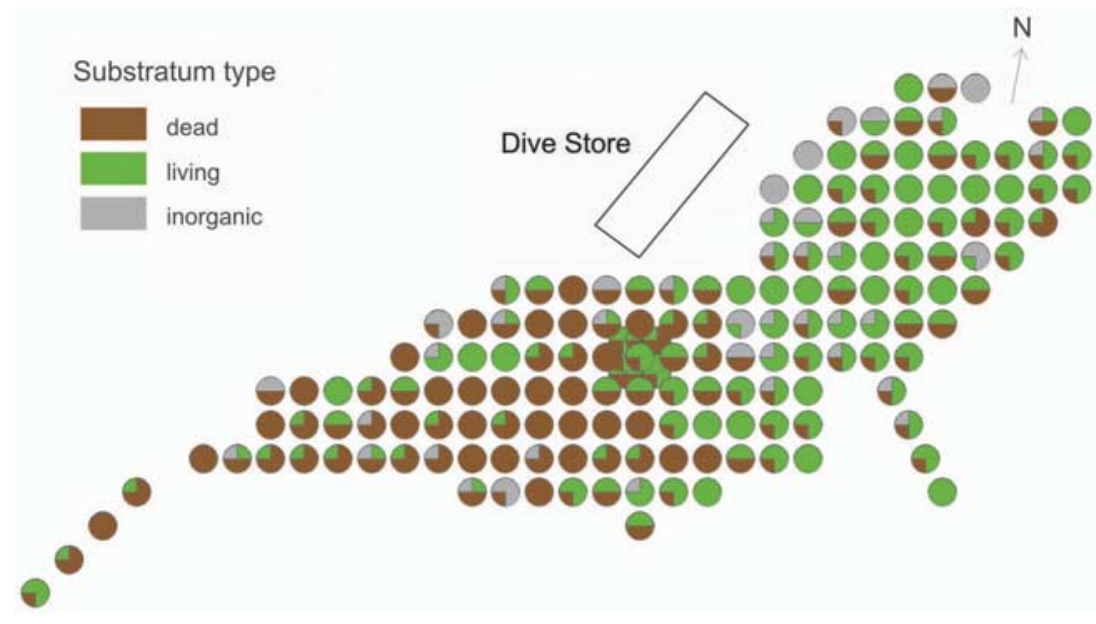

Fig. 3. Distribution of different substrates around the main introduction site. Each circle represents the proportion of each substratumtype found in the four replicates from each sample site. The samples locations are on a $5 \mathrm{~m} \times 5 \mathrm{~m}$ grid, with samples sites around the likely introduction site on a $1.5 \times 1.5 \mathrm{~m}$ grid.

Quantification of non-native species on a transect away from the main introduction site

In January 2008 sampling points were identified at $20 \mathrm{~m}$ intervals for $280 \mathrm{~m}$ along a direct line between the introduction site and the $93 \mathrm{~m}$ spot height point on Observation Bluff (bearing of $135^{\circ}$; see Fig. 1, blue line). Triplicate soil cores were collected within a $5 \mathrm{~m}$ radius of each sample point. Samples were not collected randomly, but cores were collected from dead moss or peat where available. Individual samples were placed in sample bags and returned to the UK at $4^{\circ} \mathrm{C}$ for analysis.

\section{Quantification of non-native species along paths}

In February 2009 a series of cores were collected along the three main paths leading away from the research station (see Fig. 1). One path followed the coast for about $100 \mathrm{~m}$ and then climbed steeply to about $75 \mathrm{~m}$ above sea level ('Stone Chute'; yellow line). This is the main path from the research station providing access to the main body of the island, and is used frequently by station staff. A second path ('Back Slope'; red line) from the station climbed steadily to a study site about
$60 \mathrm{~m}$ a.s.l. This path is used regularly, but less than the Stone Chute path. The third path (Study Site; green line) leads to a small study site (c. $40 \mathrm{~m}$ a.s.1.) established in 1991 and has had much less use. For the Stone Chute and Back Slope paths, three sets of three samples were collected at c. $20 \mathrm{~m}$ intervals along the paths. One set was taken from the centre of the path, one each from about $10 \mathrm{~m}$ to either side. The samples were collected and analysed in a similar manner to those collected previously. For the Study Site path, triplicate samples were taken only from the path itself, and no on-path/off-path comparison of larvae concentrations was made.

\section{Enumeration of non-native species in soil cores}

Cores were removed from their sample bags, weighed and placed on trays for examination. Cores containing moss were teased apart using a pair of fine forceps while more friable material (peat and soil) was spread thinly over a white tray. Any midge larvae and enchytraeid worms were carefully removed and counted during a $15 \mathrm{~min}$ examination period using a low power stereo microscope. Cores were normally examined within four months of collection. Dead or

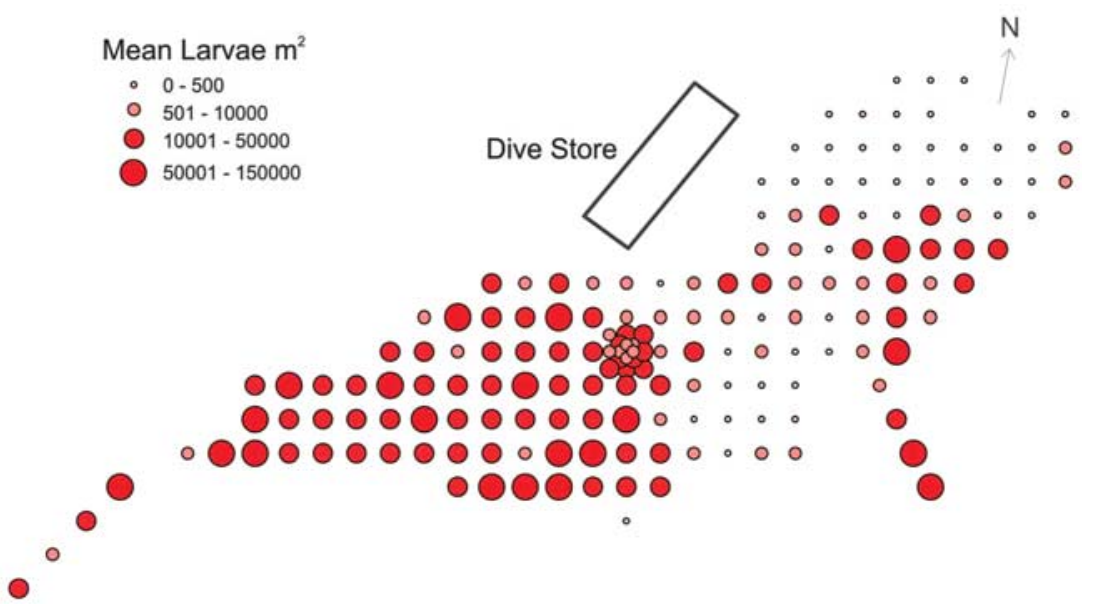

Fig. 4. Distribution of E. murphyi larvae around the main introduction site. Circles represent the mean number of E. murphyi larvae $\mathrm{m}^{-2}$ at each sample site. 
decomposing midge larvae and worms were rarely found, suggesting that transport back to the UK had little impact on invertebrate survival; nevertheless a small number of dead organisms may have decayed beyond recognition. A note was made of the sample mass, location and predominant substratum type (three categories: i) dead organic material (dead moss and peat), ii) living organic material (mostly moss), and iii) inorganic material (stony soil and gravel)). The concentrations of larvae in each substratum were compared by one-way analysis of variance with Tukey's test using the MINITAB 15.1 package.

\section{Wind speed and direction}

Wind speed and direction was recorded near Signy Research Station using a series of anemometers between 1957 and 1995 to show the influence of wind on the distribution of the midge.

\section{Estimation of larval mean fresh and dry mass}

Records were made of the individual masses of 25 randomly selected fresh larvae, after which dry mass was measured by drying the larvae to constant mass at $45^{\circ} \mathrm{C}$.

\section{Results}

Quantification of non-native species in different substrata around the main introduction site

Figure 3 shows the substrata sampled in the $5 \mathrm{~m} \times 5 \mathrm{~m}$ grid around the main introduction site. Generally, dead moss and peat was the most common substrate in cores taken to the west while live moss was most common to the east.

Figure 4 shows the mean number of E. murphyi at each sample position. Larvae numbers were generally greater to the west of the main introduction site, although high larval densities were located at some other sites. The maximum number of larvae found in any single core within the grid was 150 which equates to over $3 \times 10^{5}$ larvae $\mathrm{m}^{-2}$. The mean concentration of larvae found in the surveyed area around the introduction site was $2.11 \times 10^{4}$ larvae $\mathrm{m}^{-2}(716$ cores). However, on closer analysis, mean larval concentration varied to some degree depending upon the substratum type: i) dead organic material, $3.34 \times 10^{4}$ $\left(\mathrm{SD} \pm 4.2 \times 10^{4}\right)(305$ cores $)$, ii) living organic material, $1.16 \times 10^{4}\left(\mathrm{SD} \pm 4.1 \times 10^{4}\right)(344$ cores $)$, and iii) inorganic material, $1.52 \times 10^{4}\left(\mathrm{SD} \pm 2.5 \times 10^{4}\right)(67$ cores $)$. Larval concentrations in dead organic material were significantly different to those in living organic material and inorganic material $(P<0.05)$. Larvae concentrations in living organic material and inorganic material were not significantly different $(P>0.05)$.

Christensenidrilus blocki was absent from the cores taken directly within the main introduction site, and was found in only three dead moss cores (containing 1, 5 and 12
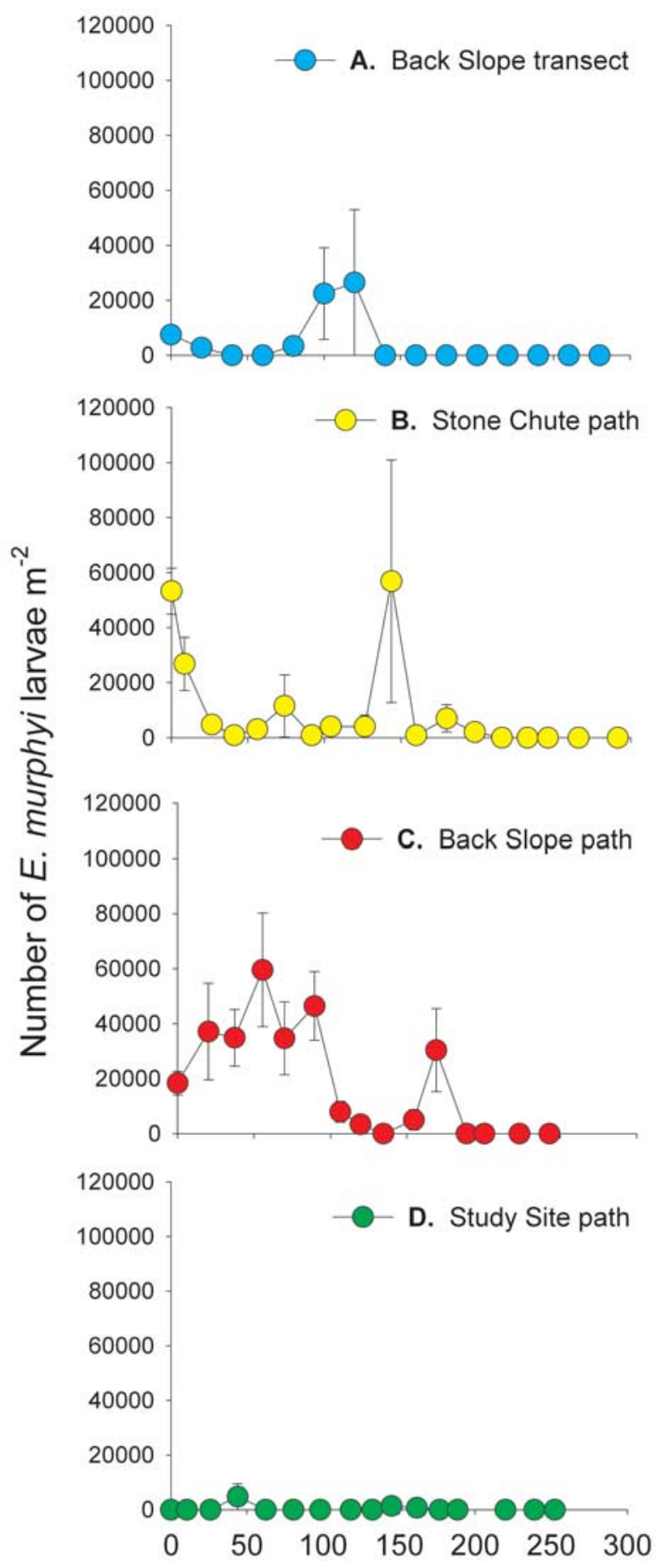

Distance from start of path/transect $(\mathrm{m})$

Fig. 5a-d. Plot of E. murphyi larval numbers along a transect and paths leading away from the research station. Distances between the likely introduction site (labelled A in Fig. 1) and the start of the Stone Chute, Back Slope and Study Site paths are 51,55 and $71 \mathrm{~m}$, respectively.

worms) at two sample sites situated $5 \mathrm{~m}$ apart and $\sim 7 \mathrm{~m}$ south of the main introduction site. The mean number of 
worms at each site was $c .6600 \mathrm{~m}^{-2}$ and $2000 \mathrm{~m}^{-2}$, although there was a high degree of aggregation. It is possible that C. blocki was more widely distributed, but either at a greater depth or in numbers sufficiently low to be missed by our sampling method. No other enchytraeid worms were found during the study.

\section{Quantification of larvae on a transect away from the main introduction site}

Figure 5a shows the mean number of midge larvae per core sampled at $20 \mathrm{~m}$ intervals along a line from the probable introduction site towards Observation Bluffs. Comparatively low numbers of larvae were found close to the introduction site $\left(<1.0 \times 10^{4} \mathrm{~m}^{-2}\right)$ with none found at the 40 and $60 \mathrm{~m}$ sample points. However, the highest numbers were found between 80 and $120 \mathrm{~m}$ from the introduction site, with one replicate core (at $120 \mathrm{~m}$ ) containing $8.0 \times 10^{4}$ larvae $\mathrm{m}^{-2}$. No larvae were detected in core samples beyond the $120 \mathrm{~m}$ point, which may indicate either a maximum extent of larval colonization along that line, or that larval concentrations were below the sensitivity of the sampling methodology. This transect line crossed undisturbed areas and did not follow any particular paths. However, it did cross the Back Slope path at c. $75 \mathrm{~m}$ a.s. 1 .

Quantification of larvae on paths leading away from the research station

There was no significant difference between the numbers of larvae in cores collected on the Stone Chute or Back Slope paths compared with the numbers of larvae in cores collected either side of the path $(c .10 \mathrm{~m}$ to either side of the path), and thus these data were pooled. Figure $5 \mathrm{~b}-\mathrm{d}$ shows the concentrations of larvae along the Stone Chute, Back Slope and Study Site paths, respectively. Therefore, for Fig. $5 b \&$ c, each data point represents the counts from nine cores per data point). Figure $5 \mathrm{~d}$ shows the mean values of three on-path replicates for the Study Site path.

Overall, larvae were not recorded on or around any of the paths beyond $198 \mathrm{~m}$ along a path, which is around $220 \mathrm{~m}$ from the main introduction site. Larval concentration on the Stone Chute path declined initially with distance from the station; however, a high mean concentration of almost $5.7 \times 10^{4}$ larvae $\mathrm{m}^{-2}$ was encountered $144 \mathrm{~m}$ from the start of the path (including a single core with a concentration of $4.1 \times 10^{5}$ larvae $\mathrm{m}^{-2}$ ). The Back Slope path showed high levels of colonization by the midge for the first $90 \mathrm{~m}$, with mean larval concentrations of between $1.8 \times 10^{4}$ and $6.0 \times 10^{4}$ larvae $\mathrm{m}^{-2}$. However, at points beyond $90 \mathrm{~m}$, numbers were less than $1 \times 10^{4}$ larvae $\mathrm{m}^{-2}$, with the exception of a point $169 \mathrm{~m}$ along the path where over $3.0 \times 10^{4}$ larvae $\mathrm{m}^{-2}$ were found. On the Study Site path, larvae were largely absent, but where found, were in concentrations of less than $5.0 \times 10^{3}$ larvae $\mathrm{m}^{-2}$.
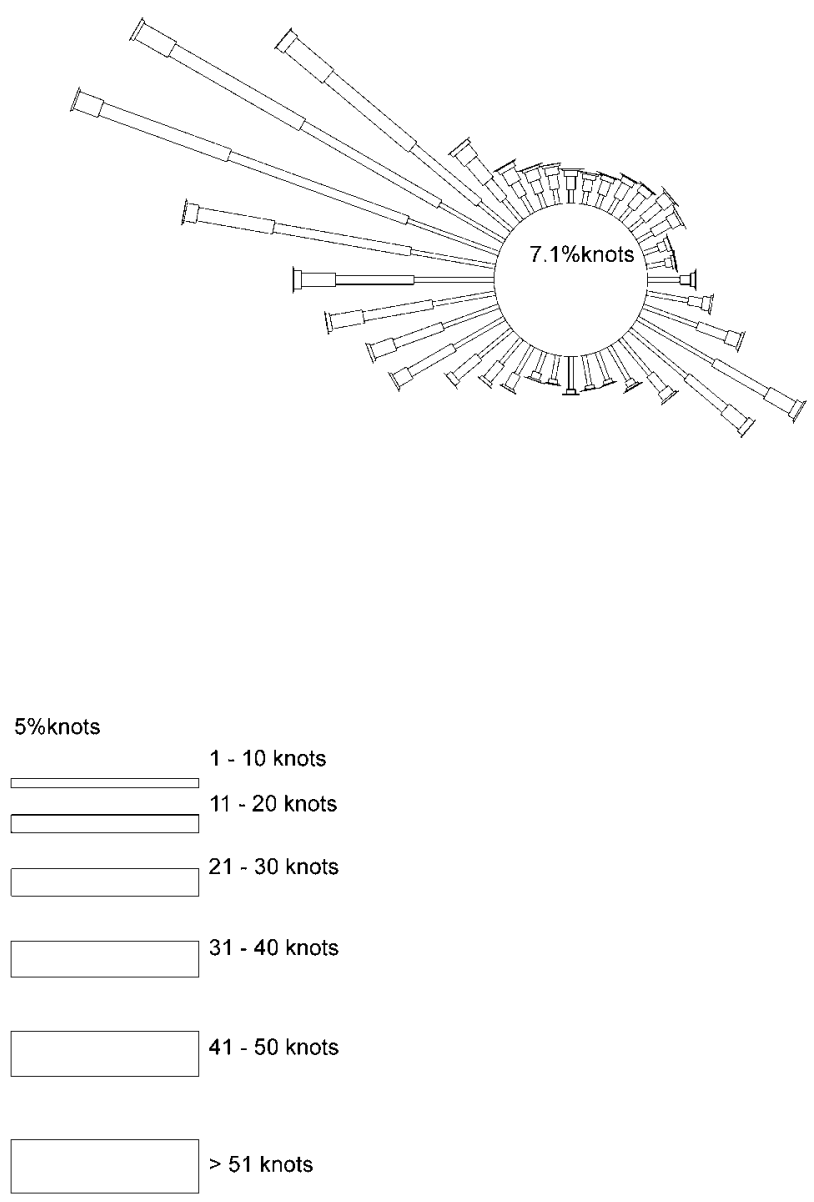

Fig. 6. Wind speed and direction recorded at the meteorological station at Signy Research Station (summary of data collected between 1957 and 1995).

\section{Wind speed and direction}

Figure 6 shows the wind speed and direction recorded at the meteorological station at Signy Research Station. Strong south-easterly and north-westerly winds dominate.

\section{Estimation of larval mean fresh and dry mass}

The water content of the midge larvae varied considerably from 3.00 to $1.71 \mathrm{~g} \mathrm{~g}^{-1}$ with a mean of $2.65 \pm 0.46$. The mean fresh mass was $1.36 \mathrm{mg}(\mathrm{SD} \pm 0.45)$ and the mean dry mass $0.36 \mathrm{mg}(\mathrm{SD} \pm 0.13)$.

\section{Discussion \\ Distribution and colonization success}

This study is the first detailed survey of the distribution of Antarctica's only two known terrestrial non-native invertebrates, E. murphyi and C. blocki, since their probable introduction to Signy Island in the late 1960s. Table I 
Table I. Spatial distribution and concentration of E. murphyi larvae and C. blocki at Signy Island, South Orkney Islands.

\begin{tabular}{|c|c|c|c|c|}
\hline Reference & $\begin{array}{l}\text { Study } \\
\text { date(s) }\end{array}$ & $\begin{array}{l}\text { E. murphyi } \\
\text { colonized area } \\
\text { (concentration) }\end{array}$ & $\begin{array}{l}\text { C. blocki } \\
\text { colonized area } \\
\text { (concentration) }\end{array}$ & Comments \\
\hline Burns 1982 & 1980 & $\begin{array}{c}\sim 1 \mathrm{~m}^{2} \\
\left(13000 \text { larvae } \mathrm{m}^{-2}\right)\end{array}$ & $\sim 1 \mathrm{~m}^{2}$ & $\begin{array}{l}\text { 'Larvae have been found in highest densities }\left(1.3 \mathrm{~cm}^{-2}\right) \\
\text { in the top few millimetres of almost pure stands of } \\
\text { Polytrichum alpestre that have colonized the site.' }\end{array}$ \\
\hline Block et al. 1984 & $1981 / 82$ & $\begin{array}{l}\quad>1 \mathrm{~m}^{2} \\
\left(25718 \text { larvae } \mathrm{m}^{-2}\right. \\
\text { highly aggregated })\end{array}$ & $\begin{array}{l}\sim 1 \mathrm{~m}^{2} \\
\left(3243 \text { worms m} \mathrm{m}^{-2}\right. \\
\text { highly aggregated })\end{array}$ & $\begin{array}{l}\text { 'Extensive examination of the ground immediately } \\
\text { adjacent to the site has produced little evidence of } \\
\text { spread by either taxon.' } \\
\text { 'A single larva of E. murphyi was found } 40 \mathrm{~cm} \text { from the } \\
\text { edge of the site in } 1982 \text {, whilst six adults were seen on } \\
\text { moss } c .25 \mathrm{~m} \text { from the site the following year.' }\end{array}$ \\
\hline Cranston 1985 & $1981 / 82$ & $\left(7500\right.$ larvae $\left.\mathrm{m}^{-2}\right)$ & & \\
\hline Smith 1996 & 1989 & $\sim 2000 \mathrm{~m}^{2}$ & $\sim 1 \mathrm{~m}^{2}$ & $\begin{array}{l}\text { No enchytraeids were found beyond the [introduction] } \\
\text { site but, by } 1989 \text {, chironomid larvae had spread through } \\
\text { out a radius of about } 25 \mathrm{~m} \text { from the original } \\
\text { experimental plot.' }\end{array}$ \\
\hline Convey 1992 & $\begin{array}{l}1989 / 90 \\
1990 / 91\end{array}$ & $>600 \mathrm{~m}^{2}$ & & $\begin{array}{l}\text { 'The species [E. murphyi] now occurs frequently within } \\
\text { an area of at least } 600 \mathrm{~m}^{2} \text { centred on the point of origin.' }\end{array}$ \\
\hline Smith, unpublished data & 1991 & & (?) & Enchytraeid worm found c. $10 \mathrm{~m}$ from introduction site. \\
\hline
\end{tabular}

summarizes the limited available data on the extent and concentration of the two species since 1982, largely in the form of ad hoc observations. Most previous reports detail the extent of the midge and worm centred on the main introduction site (Fig. 1, site A). However, it is possible that the non-native species were introduced to more than one site in the immediate vicinity of the station, e.g. Fig. 1, site B (R.I.L. Smith, personal communication 2008).

Frenot et al. (2005) defined a persistent alien as having 'survived, established and reproduced for many years in a restricted locality, but has not expanded range from that location'. In this context, after around 15 years with apparently little expansion from the original establishment site, E. murphyi has extended its distribution range since at least the mid-1980s to an area of $c .35000 \mathrm{~m}^{2}$ and as a result its colonization status may no longer be considered 'persistent'. Further research is required to show whether or not the midge should be considered an invasive alien, i.e. has spread into native communities and displaced native species (Frenot et al. 2005).

If $E$. murphyi has, at a minimum, a two year life-cycle as suggested by Convey \& Block 1996, then the midge has survived on Signy Island for around 20 generations. We do not know if the rate of colonization of new habitat on Signy by the midge has increased, though any change could be due to a reduction in the severity of environmental conditions on the island due to climate change, or a change in the physiology of the midge. Alternatively, earlier reports on the extent of the area colonized by the larvae may have been of limited accuracy and the midge population may be undergoing an unchanged rate of expansion made possible by existing behavioural and physiological adaptations.

Within the $2775 \mathrm{~m}^{2}$ grid surveyed around the introduction site (equal in area to a $53 \mathrm{~m} \times 53 \mathrm{~m}$ square) 
there were estimated to be $5.9 \times 10^{7}$ larvae. Using our rough calculation of mean larval mass, this may equate to a larval fresh mass of up to $80 \mathrm{~kg}$. With mean fresh and dry masses estimated to be $c .29$ and $8 \mathrm{~g} \mathrm{~m}^{-2}$, respectively, it is likely that the midge larvae are having an impact on nutrient turnover in the colonized area. In contrast with E. murphyi, since the 1960 s, the C. blocki population has not expanded its spatial distribution greatly, being absent from the introduction site and only found in two locations $\sim 7 \mathrm{~m}$ away. Within the sub-Antarctic, invasive status of the non-native earthworms Dendrodrilus rubidus tenuis (Eisen) has been reported to vary with location; on Possession Island it has not spread much beyond the research station and is persistent, while on Kerguelen it is invasive (Frenot et al. 2005). Little information exists on non-native invertebrates that have been transient over a timescale of decades within the Antarctic and sub-Antarctic literature although there are several reports of winged insects existing as transient aliens on sub-Antarctic islands (Hänel et al. 1998, Greenslade et al. 1999, Convey 2005). In the southern polar region, invertebrate invasive species have received relatively little attention by environmental managers compared to invasive vertebrates such as rats, cats and rabbits (Chapuis et al. 2001, Bester et al. 2002). Nevertheless, sub-Antarctic invasive invertebrates have been shown capable of altering ecosystem structure and function (Chown et al. 2008). A predatory beetle, Trechisibus antarcticus Dejean, introduced to South Georgia and invading the coastal lowlands around Husvik, has affected the endemic detritivorous/herbivorous beetle Hydromedion sparsutum Müll by decreasing its abundance and causing an increase in mean body size (Ernsting et al. 1995, 1999). On Kerguelen, the flightless cold-temperate predatory carabid beetle Merizodus soledadinus Guerin-Méneville threatens population of native invertebrates, particularly in the littoral zone, while the necrophagous blowfly Calliphora vicina Robineau-Desvoidy may lead to intra-specific resource competition between the larvae of the native wingless fly Anatalanta aptera Eaton (Chevrier et al. 1997, Frenot et al. 2008). In lowland plant communities of sub-Antarctic Marion Island, caterpillars of the indigenous flightless moth Pringleophaga marioni Viette were thought to dominate nutrient cycling. However, Hänel \& Chown (1998) suggested that the introduced parthenogenetic chironomid midge, Limnophyes minimus Meigen, may be undertaking substantial nutrient turnover comparable with that of $P$. marioni.

\section{Dispersal processes}

The midge larvae have an aggregated and patchy distribution in the vicinity of the Signy Island Research Station but it is unclear if they are being dispersed by processes other than crawling. Wing reduction (brachyptery) is a characteristic exhibited by some insects found in low temperature or high wind environments such as exist in Antarctica (e.g. Belgica antarctica Jacobs) and the sub-Antarctic islands (Convey \& Block 1996). The wind direction around the research station is often from the WNW, which could blow the midge adults up the back slope (Fig. 6). However, wind patterns can differ greatly near the ground surface and if wind were a successful dispersal method, we might expect a greater distribution of the midge larvae in suitable substrates further from the introduction site, given that up to 40 years may have elapsed since the initial introduction of the midge. Temporary drainage streams are unlikely to assist in adult midge distribution as all streams in the area flow north towards the main introduction site and the sea. Birds may play a part in distribution to other areas of the South Orkney Islands and beyond, but at present we have no data to confirm this.

We found no evidence that midge larvae numbers were higher on the paths than on similar substrates off the paths. However, other workers have shown human movement along paths to be an effective means of aiding dispersal of non-native species (see Frenot et al. 2008). An island-wide survey was beyond the scope of this study; however, it is possible that the midge and/or worm have been distributed to other areas of Signy Island in peat or mud attached to clothing, footwear or equipment. Although no evidence supporting this has been reported by other researchers on the island, a generic challenge to any assessment of the status and distribution of small terrestrial invertebrates such as these is the ability to detect new founding populations at an early stage after establishment.

\section{Habitat availability and colonization}

Physical features around the main introduction sites (e.g. the research station to the north, ocean to the west and cliffs to the south-west) limit the area where suitable substrata are available for colonization by the midge larvae and worm. Our study has shown that the midge larvae have a habitat preference for dead moss and peat substrata over stony soil and gravel or live moss and other plants. Eretmoptera murphyi is likely to be a detritovore, and live mosses may not be a favourable substratum (Convey \& Block 1996). Mosses with dense, closely packed stems may restrict access of the larvae to sub-surface layers, although the midge has also been reported in association with lichens and in particular Cladonia spp. (Block et al. 1984). Given that the midge larvae can colonize a wide range of substratum types, there is clearly a large area of suitable habitat on Signy Island as a whole. On South Georgia, E. murphyi is found in fellfield areas up to $300 \mathrm{~m}$ a.s.l. in the moss Racomitrium austro-georgicum (Ring et al. 1990), while on Signy Island it has been found up to $40 \mathrm{~m}$ a.s.l. mainly in peat (this study).

Signy Island has undergone substantial deglaciation over the last 50 years (Smith 1990), creating new areas of icefree ground suitable for colonization by vegetation and 
Table II. Colonization status of known non-native species in the Antarctic terrestrial environment.

\begin{tabular}{|c|c|c|c|c|c|c|}
\hline Species & Location & Date introduced & Colonization status & Colonization area & Notes & References \\
\hline Eretmoptera murphyi & $\begin{array}{c}\text { Signy Research Station, } \\
\text { South Orkney Islands, } \\
\text { Scotia Arc. }\end{array}$ & 1967, 1968(?) & Expanding & $\sim 35000 \mathrm{~m}^{2}$ & & $\begin{array}{l}\text { this manuscript and } \\
\text { references therein }\end{array}$ \\
\hline Christensenidrilus blocki & $\begin{array}{c}\text { Signy Research Station, } \\
\text { South Orkney Islands, } \\
\text { Scotia Arc. }\end{array}$ & $1967,1968(?)$ & Persistent & $<150 \mathrm{~m}^{2}$ & & $\begin{array}{l}\text { this manuscript and } \\
\text { references therein }\end{array}$ \\
\hline Роа аппиа & $\begin{array}{l}\text { Arctowski Station, } \\
\text { King George Island, } \\
\text { South Shetland Islands }\end{array}$ & $1985 / 86$ & Expanding & $\begin{array}{l}\text { Has spread over } 500 \mathrm{~m} \text { into the } \\
\text { vicinity of the nearby Antarctic } \\
\text { Specially Protected Area (ASPA) } \\
128 \text { Western Shore of Admiralty } \\
\text { Bay. Expansion may be } \\
\text { attributed to regional warming }\end{array}$ & $\begin{array}{l}\text { 1985/86: first found in metal grating at } \\
\text { Arctowski Station main building. 1990: } \\
\text { spread to greenhouse area and above } \\
\text { subterranean hot water pipes within a } \\
\text { single area of } c .0 .4 \mathrm{~km}^{2} .1991 / 92 \text { : found } \\
\text { in a number of locations with disturbed } \\
\text { ground. } 2005 / 06 \text { : found growing } \\
\text { amongst indigenous plant communities } \\
\text { for the first time. Poa annua invasive on } \\
\text { four sub-Antarctic islands }\end{array}$ & $\begin{array}{l}\text { Olech } 1996 \\
\text { Smith } 1996 \\
\text { Olech } 2003 \\
\text { Frenot et al. } 2005 \\
\text { Chwedorzewska } 2008\end{array}$ \\
\hline Poa pratensis & $\begin{array}{l}\text { Primavera Station, } \\
\text { Cierva Point, } \\
\text { Palmer Archipelago, } \\
\text { Antarctic Peninsula }\end{array}$ & $1954 / 55$ & Persistent & $\begin{array}{l}\text { Limited to an area c. } 40 \mathrm{~cm} \\
\text { across, possibly because the } \\
\text { microclimate is unsuitable } \\
\text { for growth outside this } \\
\text { restricted area. }\end{array}$ & $\begin{array}{l}\text { Transplant experiments of Nothofagus } \\
\text { antarctica and } N \text {. pumilo in soil imported } \\
\text { from Ushuaia (Terra del Fuego). } \\
P \text {. pratensis invasive on three } \\
\text { sub-Antarctic islands. }\end{array}$ & $\begin{array}{l}\text { Corte } 1961 \\
\text { Smith } 1996 \\
\text { (Last report 1995) } \\
\text { Frenot et al. 2005 }\end{array}$ \\
\hline Poa trivialis & $\begin{array}{l}\text { Syowa Station, } \\
\text { Enderby Land, } \\
\text { East Antarctica }\end{array}$ & 1993(?) & Eradicated & Single plant & $\begin{array}{l}\text { Removed in } 2007 \\
\text { (S. Imura, personal communication } \\
\text { 2007) }\end{array}$ & Japan 1996 \\
\hline
\end{tabular}


associated fauna at both lower and higher altitudes. The midge may be restricted to lower altitudes on Signy Island as its physiological pre-adaptations may not be adequate to survive the more severe climatic conditions likely to be experienced at higher altitude. Some doubt remains as to whether or not E. murphyi larvae are freeze susceptible (Block et al. 1984) or freeze tolerant (Harrisson \& Block 1988, Convey \& Block 1996), and further clarification is needed. Block et al. (1984) found trehalose, glucose, fructose and glycerol in low concentrations $(<1 \%$ of fresh body weight of larvae, pupae and adults), but these concentrations are unlikely to have a significant effect on the organism's supercooling capacity. Nevertheless, at both South Georgia and Signy Island, the soil and moss habitat chosen by the midge allows it to be buffered from climatic extremes (Davey et al. 1992). No males have been reported, and the species is considered to be an obligate parthenogenetic species, which may be an adaptation to allow rapid reproduction under harsh conditions (Cranston 1985, Convey 1992, Hullé et al. 2003). Further expansion of the midge may not be limited by direct competitors or predators, as these are largely absent on Signy Island. Of the five known alien species in terrestrial Antarctica, E. murphyi and P. annua (King George Island, South Shetland Islands) may currently present the highest risk to their local indigenous communities (see Table II). Their impact on the Antarctic terrestrial ecosystem may be increased greatly if they are distributed to other Antarctic locations, by either natural or anthropogenic processes.

\section{Past and current biosecurity precautions}

Those undertaking the transplantation experiments at Signy Research Station were aware of the recommendations for conservation of the Antarctic flora and fauna mentioned in the Antarctic Treaty, and a specific permit was obtained for their work (Edwards 1980). Measures were taken to ensure that the imported plants did not spread beyond the study sites. After completion of the transplantation experiments in February 1973, all plant remains were removed and burnt, and the imported soil disposed of at sea. However, these measures may have proven inadequate to prevent the establishment of the enchytraied worm and chironomid midge.

There is no evidence to suggest that either E. murphyi or C. blocki have been translocated from Signy to other UK research stations served by the British Antarctic Survey ships that resupply Signy Research Station. However, both species were found recently in soil and vegetation moved inadvertently on industrial plant equipment between South Georgia and Rothera Research Station (Adelaide Island, Antarctic Peninsula) (Hughes et al. 2009). Nevertheless, the risk of expanding the area colonized by these nonnative species through human activities should be reduced to a minimum. The British Antarctic Survey now requires everyone leaving Signy Island to wash soil and mud from their footwear using disinfectant at the earliest opportunity and before landing at any other Antarctic location. Eradication of C. blocki, or possibly E. murphyi, may be feasible, but would result in the destruction of a large area of rich terrestrial habitat, of considerable scientific value, close to the research station. The implications of any eradication attempt would need to be considered carefully.

\section{Acknowledgements}

The authors would like to thank Paul Bridge, Jessica Royles and Akinori Takahashi for help with sample core collection, Steve Colwell for meteorological data, Peter Fretwell for map preparation, Michael Thorne for help with the climate data, Anna Malaos for help with core sorting, Pete Bucktrout and Chris Gilbert for assistance with photography and Pete Convey for general project discussions and reviewing a draft of the manuscript. This paper contributes to the British Antarctic Survey's Polar Science for Planet Earth core programmes 'Environment Office: Long Term Monitoring and Survey' and 'Ecosystems', and the international SCAR EBA (Evolution and Biodiversity in Antarctica) and International Polar Year 'Aliens in Antarctica' research programmes. We thank Dr Yves Frenot and an unknown reviewer for their comments on the manuscript.

\section{References}

Allegrucci, G., Carchini, G., Todisco, V., Convey, P. \& Sbordoni, V. 2006. A molecular phylogeny of Antarctic chironomidae and its implications for biogeorgraphical history. Polar Biology, 29, 320-326.

Barnes, D.K.A., Hodgson, D.A., Convey, P., Allen, C. \& Clarke, A. 2006. Incursion and excursion of Antarctic biota: past, present and future. Global Ecology and Biogeography, 15, 121-142.

Bester, M.N., Bloomer, J.P., Van Aarde, R.J., Erasmus, B.H., van Rensburg, P.J.J., Skinner, J.D., Howell, P.G. \& Naude, T.W. 2002. A review of the successful eradication of feral cats from sub-Antarctic Marion Island, Southern Indian Ocean. South African Journal of Wildlife Research, 32, 65-73.

Block, W., Burn, A.J. \& Richard, K.J. 1984. An insect introduction to the maritime Antarctic. Biological Journal of the Linnean Society, 23, 33-39.

Block, W. \& Christensen, B. 1985. Terrestrial enchytraeidae from South Georgia and the maritime Antarctic. British Antarctic Survey Bulletin, No $69,65-70$.

Bokhorst, S., Huiskes, A., Convey, P., van Bodegom, P.M. \& Aerts, R. 2008. Climate change effects on soil arthropod communities from the Falkland Islands and the maritime Antarctic. Soil Biology and Biochemistry, 40, 1547-1556.

Brundin, L. 1970. Diptera: Chironomidae of South Georgia. Pacific Insects Monographs, 23, 276.

BuRn, A.J. 1982. A cautionary tale - two recent introductions to the maritime Antarctic. Comité National Francais des Recherches Antarctiques, 51, 521.

Chapuis, J.-L., le Roux, V., Asseline, J., Lefevre, L. \& Kerleau, F. 2001. Eradication of the rabbit (Oryctolagus cuniculus) by poisoning, on three islands of the subantarctic archipelago of Kerguelen. Wildlife Research, 28, 323-331. 
Chevrier, M., Vernon, P. \& Frenot, Y. 1997. Potential effects of two alien insects on a subantarctic wingless fly in the Kerguelen Islands. In Battaglia, B., Valencia, J. \& Walton, D.W.H., eds. Antarctic communities: species, structure and survival. Cambridge: Cambridge University Press, 424-431.

Chown, S.L., Lee, J.E. \& Shaw, J.D. 2008. Conservation of Southern Ocean Islands: invertebrates as exemplars. Journal of Insect Conservation, 12, 277-291.

Chwedorzewska, K.J. 2008. Poa апnиa L. in Antarctic: searching for the source of introduction. Polar Biology, 31, 263-268.

COMnaP (Council Of Managers Of National Antarctic Programs). 2009. Antarctic facilities. Access via www.comnap.aq/facilities. Accessed 10 Mar 2009.

Convey, P. 1992. Aspects of the biology of the midge, Eretmoptera murphyi Schaeffer (Diptera: Chironomidae), introduced to Signy Island, maritime Antarctica. Polar Biology, 12, 653-657.

Convey, P. 2005. Recent lepidopteran records from sub-Antarctic South Georgia. Polar Biology, 28, 108-110.

Convey, P. 2008. Non-native species in the Antarctic terrestrial environment. In Rogan-Finnemore, M., ed. Non-native species in the Antarctic: proceedings. Christchurch: Gateway Antarctica Special Publication, 97-130.

Convey, P. \& Block, W. 1996. Antarctic Diptera: ecology, physiology and distribution. European Journal of Entomology, 93, 1-13.

Convey, P., Gibson, J.A.E., Hillenbrand, C.-D., Hodgson, D.A., Pugh, P.J.A., Smellie, J.L. \& Stevens, M.I. 2008. Antarctic terrestrial life challenging the history of the frozen continent? Biological Reviews, 83 , 103-117.

CoRTE, A. 1961. La primera fanerogama adventicia hallada en el continente Antartico. Contribucion del Instituto Antdrtico Argentino, 62, 1-14.

CRANSTON, P.S. 1985. Eretmoptera murphyi Schaeffer (Diptera: Chironomidae), an apparently parthogenetic Antarctic midge. British Antarctic Survey Bulletin, No 66, 35-45.

DAVEY, M.C., PICKUP, J. \& BLOCK, W. 1992. Temperature-variation and its biological significance in fellfield habitats on a maritime Antarctic island. Antarctic Science, 4, 383-388.

Dózsa-Farkas, K. \& Convey, P. 1997. Christensenia, a new terrestrial enchytraeid genus from Antarctica. Polar Biology, 17, 482-486. (and correction Polar Biology, 20, 292.)

EDWARDS, J.A. 1968. Preliminary investigations into vascular plant growth at Signy and South Georgia in the austral summer of 1967-1968. British Antarctic Survey internal report. British Antarctic Survey Archives No. AD6/2H/1968/N1.

EDWARDS, J.A. 1980. An experimental introduction of vascular plants from South Georgia to the maritime Antarctic. British Antarctic Survey Bulletin, No 49, 7380.

Edwards, J.A. \& Greene, D.M. 1973. The survival of Falkland Island transplants at South Georgia and Signy Island, South Orkney Islands. British Antarctic Survey Bulletin, Nos. 33 \& 34, 33-45.

Ernsting, G., Block, W., Macalister, H. \& Todd, C. 1995. The invasion of the carnivorous carabid beetle Trechisibus antarcticus on South Georgia (subantarctic) and its effect on the endemic herbivorous beetle Hydromedion spasutum. Oecologia, 103, 34-42.

ERnsting, G., Brandjes, G.J., Block, W. \& Isaaks, J.A. 1999. Life-history consequences of predation for a subantarctic beetle: evaluating the contribution of direct and indirect effects. Journal of Animal Ecology, 68, 741-752.

Frenot, Y., Chown, S.L., Whinam, J., Selkirk, P.M., Convey, P., Skotnicki, M. \& Bergstrom, D.M. 2005. Biological invasions in the Antarctic: extent, impacts and implications. Biological Reviews, 80, 45-72.
Frenot, Y., Convey, P., Lebouvier, M., Chown, S.L., Whinam, J., Selkirk, P.M., Skotnicki, M. \& Bergstrom, D.M. 2008. Antarctic and Subantarctic biological invasions: sources, extents, impacts and implications. In RoganFinNemore, M., ed. Non-native species in the Antarctic: proceedings. Christchurch: Gateway Antarctica Special Publication, 53-96.

Greenslade, P., Farrow, R.A. \& Smith, J.M.B. 1999. Long distance migration of insects to a subantarctic island. Journal of Biogeography, 26, 1161-1167.

Hänel, C. \& Chown, S.L. 1998. The impact of a small, alien invertebrate on a sub-Antarctic terrestrial ecosystem: Limnophyes minimus (Diptera, Chironomidae) at Marion Island. Polar Biology, 20, 99-106.

Hänel, C., Chown, S.L. \& DAvies, L. 1998. Records of alien insect species from sub-Antarctic Marion and South Georgia islands. African Entomology, 6, 366-369.

Harrisson, P.M. \& Block, W. 1988. Survival of freezing in a midge introduced to the Antarctic. Cryo-Letters, 9, 433.

Hughes, K.A., Convey, P., Maslen, N.R. \& Smith, R.I.L. 2009. Accidental transfer of non-native soil organisms into Antarctica on construction vehicles. Biological Invasions, 10.1007/s10530-009-9508-2.

Hullé, M., Pannetier, D., Simon, J.-C., Vernon, P. \& Frenot, Y. 2003. Aphids of sub-Antarctic Iles Crozet and Kerguelen: species diversity, host range and spatial distribution. Antarctic Science, 15, 203-209.

iaATO (International Association Of Antarctica Tour Operators). 2009. Tourism statistics. Available at http://www.iaato.org/ tourism_stats.html [Accessed 15 Jan 2009].

JAPAN. 1996. A grass (seed plant) found in Syowa Station area, East Antarctica. Information Paper 66 for XX Antarctic Treaty Consultative Meeting, Utrecht, Netherlands, 29 April-10 May 1996.

LEE, J.E. \& ChOwn, S.L. 2009. Breaching the dispersal barrier to invasion: quantification and management. Ecological Applications, 19, 1944-1959.

Mack, R.N., Simberloff, D., Lonsdale, W.M., Evans, H., Clout, M. \& BAZZAZ, F.A. 2000. Biotic invasions: causes, epidemiology, global consequences, and control. Ecological Applications, 10, 689-710.

MCKInNEY, M.L. \& Lockwood, J. 1999. Biotic homogenization: a few winners replacing many losers in the next mass extinction. Trends in Ecology and Evolution, 14, 450-453.

OLEch, M. 1996. Human impact on terrestrial ecosystems in west Antarctica. Proceedings of the NIPR Symposium on Polar Biology, 9, 299-306.

OLEch, M. 2003. Expansion of alien vascular plant Poa апnиa L. in the vicinity of the Henryk Arctowski Station - a consequence of climate change? In Olech, M., ed. The functioning of polar ecosystems as viewed against global environmental changes. XXIX International Polar Symposium. Krakow: Institute of Botany of the Jagiellonian University, 89-90.

Ring, R.A., Block, W., Sømmer, L. \& Worland, M.R. 1990. Body water content and desiccation resistance of some arthropods from subantarctic South Georgia. Polar Biology, 10, 581-588.

Sсотt, J.J. \& KiRKPAtRicK, J.B. 2008. Rabbits, landslips and vegetation change on the coastal slopes of subantarctic Macquarie Island, 19802007: implications for management. Polar Biology, 31, 409-419.

SмITH, R.I.L. 1990. Signy Island as a paradigm of biological and environmental change in Antarctic terrestrial ecosystems. In KeRRY, K. R. \& Hempel, G., eds. Antarctic ecosystems. ecological change and conservation. Berlin: Springer, 32-50.

SмiтH, R.I.L. 1996. Introduced plants in Antarctica: potential impacts and conservations issues. Biological Conservation, 76, 135-146.

StePHENSON, J. 1932. Oligochaeta. I. Microdrili. Discovery Report, 4, 233-264.

Whinam, J., Chilcott, N. \& Bergstrom, D.M. 2005. Subantarctic hitchhikers: expeditioners as vectors for the introduction of alien organisms. Biological Conservation, 121, 207-219. 